\title{
Analisis Penggunaan Aplikasi pada Smartphone sebagai Media Pembelajaran
}

\author{
Maliqul Hafis ${ }^{1}$, Rahayu Meliasari ${ }^{2}$ \\ 1,2Program Studi Pendidikan Bahasa Inggris, IKIP PGRI Pontianak \\ E-mail: maliqulhafisphdpec@gmail.com
}

\begin{abstract}
Article Info
Article History

Received: 2021-11-01

Revised: 2021-11-20

Published: 2021-12-04

Keywords:

Smartphone;

Learning Media;

Descriptive Study.

Abstract

The use of applications on smartphones as learning media is information that must be reviewed during online learning in the post-pandemic period. The purpose of this study is to find out 1 . What smartphone applications are used by lecturers in learning English during the Covid-19 pandemic; 2. What are the benefits of smartphone applications in learning English during the Covid-19 pandemic; 3. What are the difficulties faced by lecturers in using smartphone applications for learning English during the Covid-19 pandemic. This research was conducted using a qualitative descriptive method by using an online questionnaire to collect data on 15 lecturers of the English education study program on the use of applications on smartphones as a medium for learning English. The results of this study indicate that there are several smartphone applications that are most often used as a medium for learning English by lecturers, namely WhatsApp, google classroom, google meet and Facebook. As for the benefits of smartphones in learning English, namely: smartphones as inquiry media, smartphones as communications for students, smartphones, as main information for students, smartphones as construction media. the difficulties faced by lecturers are difficulties in the internet network of students.
\end{abstract}

\begin{tabular}{l}
\hline Artikel Info \\
\hline Sejarah Artikel \\
Diterima: 2021-11-01 \\
Direvisi: 2021-11-20 \\
Dipublikasi: 2021-12-04
\end{tabular}

Kata kunci:

Smartphone;

Media Pembelajaran;

Deskriptif Studi.

\begin{abstract}
Abstrak
Penggunaan aplikasi pada smartphone sebagai media pembelajaran merupakan suatu informasi yang harus diulas selama pembelajran online dimasa post pandemi.tujuan penelitian ini adalah untuk mengetahui 1. Apa aplikasi smartphone yang digunakan dosen dalam pembelajaran Bahasa Inggris selama pandemi Covid-19; 2. Apa manfaat dari aplikasi smartphone pada pembelajaran Bahasa Inggris selama pandemi Covid-19; 3. Apa kesulitan yang dihadapi oleh dosen dalam pemanfaatan aplikasi smartphone untuk pembelajaran Bahasa Inggris selama pandemi Covid-19. Penelitian ini dilakukang dengan menggunakan metode deskriptif kualitatif dengan memanfaatkan online questionnaire untuk mengumpulkan data pada 15 dosen program studi pendidikan bahasa inggris terhadap penggunaan aplikasi pada smartphone sebagai media pembelajaran bahasa inggris. Hasil penelitian ini menunjukkan bahwa ada beberapa aplikasi smartphone yang paling sering digunakan sebagai media pembelajaran bahasa inggris oleh dosen yaitu whatsapp, google classroom, google meet dan facebook. Adpun manfaat smartphone dalam pembelajaran bahasa inggris yaitu: Smartphone Sebagai Media Inkuiri, Smartphone Sebagai Komunukasi Bagi Siswa, Smartphone, Sebagai Pusat Informasi Bagi Siswa, Smartphone Sebagai Media Konstruksi. Kesulitan yang dihadapi oleh dosen adalah kesulitan pada jaringan internet dari mahasiswa. Selain itu, kesulitan yang dihadapi adalah permasalahan pada keaslian tugas yang dikumpulkan oleh mahasiswa.
\end{abstract}

\section{PENDAHULUAN}

Selama lebih dari satu tahun lamanya, virus Covid-19 masih menjadi ancaman bagi dunia. Pandemi global telah melanda 215 negara di dunia, dan memberikan tantangan tersendiri bagi lembaga pendidikan, khususnya Perguruan Tinggi (Sadikin \& Hamidah, 2020; Widyaningrum, 2020). Aktivitas belajar mengajar yang sebelumnya berlangsung normal harus berubah secara drastis dan signifikan mengikuti berbagai peraturan yang ditetapkan oleh Pemerintah guna mengurangi penyebaran virus corona ini.
Pelaksanaan pembelajaran harus disesuaikan guna beradaptasi mengikuti ketentuan protokol kesehatan yang ditetapkan oleh WHO yaitu untuk tidak mebuat kerumunan agar mengurangi penyebaran virus. Salah satu Langkah kebijakan pemerintah adalah dengan meniadakan kegiatan pembelajaran tatap muka (konvensional), sehingga kegiatan belajar mengajar dilakukan di rumah melalui pembelajaran jarak jauh dan dengan menggunakan media online (Arizona dkk., 2020; Firman \& Rahayu, 2020; Riyanti \& Paramdia, 2020). Akhr ini dalam situasi pandemi 
banyak sekolah yang telah menerapkan proses pembelajaran online khususnya dalam pembelajaran Bahasa Inggris (Olivia dkk:2020). Mereka menggunakan aplikasi yang tersedia di internet untuk kebutuhan mereka dalam belajar Dalam prosesnya, pembelajaran elektronik merupakan hal baru bagi sekolah-sekolah di pedesaan. Setiap sekolah, baik di perkotaan dan perdesaan, pasti memiliki tantangan dan kendala tersendiri dalam pelaksanaannya secara online/daring.

Pada dasarnya, sistem belajar yang sepenuhnya dilakukan secara daring merupakan sebuah hal baru bagi para peserta didik, tidak terkecuali mahasiswa di perguruan tinggi. Guna mengatasi kecanggungan dalam proses pembelajaran Elearning yang sebelumnya tidak pernah dilakukan, maka sebaiknya pendidik harus tepat dalam memilih media pembelajaran. Dalam hal ini, smartphone merupakan salah satu media yang dapat secara efektif menunjang proses pembelajaran, karena peserta didik sudah terbiasa menggunakannya di kehidupan sehari-hari (Handal et al., 2013; MacCallum \& Jeffrey, 2009; Khitam \& Crompton, 2015).

Berbagai fitur aplikasi di smartphone memudahkan siswa dalam berkomunikasi dan berkolaborasi (Hidayati \& Diana, 2019; Pasaribu, 2018), berdiskusi, serta berbagi digital content atau materi yang terkait pembelajaran selama pembelajaran daring berlangsung (West, in Bllaca, 2016; Handal et al., 2013; Marinakou \& Giousmpasoglou, 2014; Maknuni, 2020). Aplikasi pembelajaran smartphone membantu siswa mempelajari konten dengan cara yang nyaman dan lebih mudah serta membantu siswa untuk berinteraksi satu sama lain kapan saja dan di mana saja (Huang dkk., 2010; Ferry 2008). Selain itu, instruktur dapat menyesuaikan aktivitas, praktik mengajar, dan memperkuat penilaian dan umpan balik. Ada berbagai aplikasi yang dapat digunakan dalam proses belajar mengajar (Cui \& Wang, 2008; Ferry, 2008; Mtega et al, 2012; Kizito, 2012; Rana, 2014). Beberapa diantaranya yang paling populer yaitu antara lain whatsapp, zoom meeting, gmeet, google classroom, Instagram, youtube, dan lainnya yang digunakan sebagai media belajar maupun media komunikasi bagi pendidik dan peserta didik.

Mengingat pentingnya mengetahui, mengevaluasi dan menganalisa penerapan pembelajaran menggunakan aplikasi smartphone dalam pembelajaran online, maka investigasi akan difokuskan pada implementasi penggunaan aplikasi smartphone pada dosen dengan mengacu pada taksonomi penggunaan teknologi untuk pembelajaran dari Bruce \& Levin (2001) serta kesulitan yang dihadapi guru dan siswa dalam pemanfaatan aplikasi smartphone selama pembelajaran.

\section{METODE PENELITIAN}

Penelitian ini akan menggunaan rancangan metode penelitian kualitatif untuk mencapai tujuan penelitian, yaitu untuk mengetahui mengetahui aplikasi smartphone yang digunakan dalam pembelajaran Bahasa Inggris selama pandemic Covid-19 beserta manfaat-manfaatnya, dan mengetahui kesulitan yang dihadapi oleh guru dan siswa dalam pemanfaatan aplikasi smartphone untuk pembelajaran Bahasa Inggris selama pandemi Covid-19, Subjek penelitian adalah dosen yang mengajar pada Program Studi Pendidikan Bahasa Inggris IKIP-PGRI Pontianak. Teknik pengumpulan data dengan menggunakan komunikasi langsung dan komunikasi tak langsung, dengan alat pengumpulan data yaitu kuesioner dan wawancara. Data yang telah terkumpul dianalisis dan disajikan dalam teks naratif dan diagram untuk memudahkan. Setelah semua data dianalisis, maka dilakukan penarikan kesimpulan.

\section{HASIL DAN PEMBAHASAN}

A. Aplikasi Smartphone yang Sering Dipakai

Dari hasil analisis data, semua dosen di Prodi Pendidikan Bahasa Inggris menggunakan smartphone untuk mengajar. Pada implementasinya, aplikasi smartphone yang paling sering digunakan adalah whatsapp dengan persentase $71 \%$, sedangkan $15 \%$ untuk google classroom, $10 \%$ google meet dan $4 \%$ penggunaan pada aplikasi facebook. Dengan demikian, dapat disimpulkan bahwa aplikasi yang paling sering digunakan oleh dosen selama pembelajaran daring adalah whatsapp. Berikut ditampilkan dalam grafik berikut:

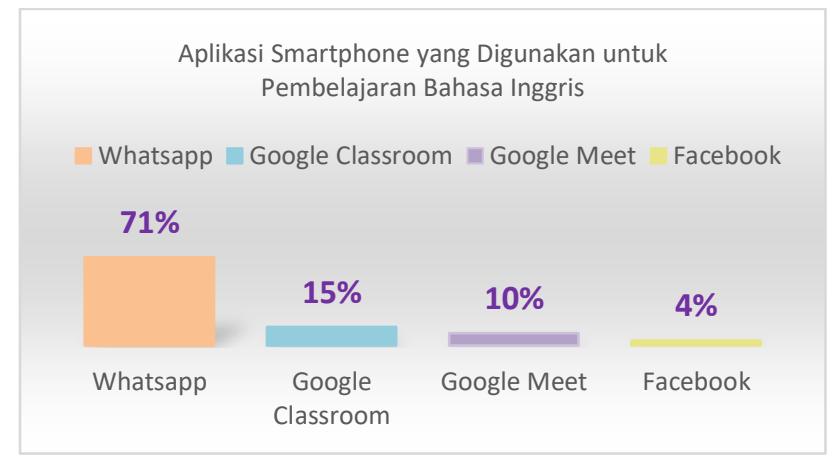

Gambar 1. Aplikasi Yang Sering Digunakan Dalam Pembelajaran Bahasa Inggris 
Dari diagram diatas, terlihat bahwa Whatsapp yang paling banyak dipilih sebagai media pembelajaran. Hal ini dikarenakan whatsapp lebih praktis untuk digunakan sehari-hari, dan sarana komunikasi yang efektif bagi mahasiswa maupun dosen. Selain itu, bisa mengantarkan pesan, gambar, video, audio dan pesan suara dengan mudah, sehingga bisa mempermudah kegiatan belajar mengajar, terutama Bahasa Inggris, hal ini sejalan dengan pendapat Hartatik \& Lestari (2021) bahwa penggunaan Whatsapp sangat populer dalam bidang pendidikan karena fitur yang ditawarkan sangat lengkap, dan tidak menbutuhkan biaya yang tinggi untuk paket data internet, mudah diakses serta mudah digunakan. Media WA terutama WAG menjadi media efektif dalam komunikasi kelompok (Setiyaningsih \& Jatmikowati, 2019; Setiyaningsih, 2020).

Berdasarkan data yang didapatkan, sebanyak 15\% dari dosen juga menggunakan google classroom untuk pembelajaran daring. Proses mengajar ini antara lain berdiskusi, membagikan materi dan membuat soal. Menurut Aunurrahman (2021) Google Classsroom mudah untuk dipelajari dan digunakan serta terdapat fitur-fitur yang membantu dalam pelaksanaan langkah-langkah pembelajaran di kelas. Hal ini juga didukung oleh penelitian dari Latif (2016) yang mengungkapkan bahwa GC dianggap sebagai platform terbaik yang mampu meningkatkan kinerja guru, selain itu GC menyediakan fasilitas yang sangat bermanfaat membantu guru untuk mengatur kelas, memanfaatkan waktu dan meningkatkan kualitas komunikasi dengan siswa. Pada dasarnya, semua dosen sudah pernah menggunakan google classroom, akan tetapi, hanya sedikit yang memanfaatkan aplikasi ini untuk pembelajaran daring pada mata kuliah yang diampu. Sejalan dengan hal tersebut, Rahmawati, et al. (2019) juga menyebutkan bahwa aplikasi Google Classroom belum banyak diketahui oleh sebagian besar pendidik di Indonesia.

Hasil analisis data menunjukkan bahwa persentase penggunaan google meet dan facebook adalah $10 \%$ dan $4 \%$ secara berturutturut. Pilihan platform video conference Google Meet menjadi pilhan bagi dosen karena selain tidak berbayar atau gratis aplikasi ini bisa digunakan di android dan PC/ Laptop. Pemanfaatan google meet sebagai media pembelajaran bertujuan untuk menciptakan keterampilan menyimak dan berbicara dalam menggunakan aplikasi google meet sebagai media pembelajaran (Juniarti \& Rasna, 2020). Facebook menjadi pilihan aplikasi yang paling sedikit dipakai oleh dosen karena di era saat ini sudah banyak aplikasi yang ditawarkan untuk dimanfaatkan sebagai media pembelajaran. Akan tetapi, facebook di perguruan tinggi memberikan beberapa wawasan yang bermanfaat untuk dosen maupun mahasiswa. Hal ini sejalan dengan pendapat Goldfarb et al., (2011) bahwa meskipun terdapat kritik untuk SJS sebagai portal yang menyebabkan prilaku tidak produktif, terdapat juga peningkatan bahwa situs ini meningkatkan kemampuan teknologi, meningkatkan ketrampilan sosial dan mempercepat pembelajaran.

B. Manfaat dari aplikasi smartphone pada pembelajaran Bahasa Inggris selama pandemi Covid-19

1) Smartphone sebagai media Inkuiri

Apakah Anda memberikan kesempatan kepada mahasiswa untuk melakukan presentasi terhadap ide/gagasan mereka?

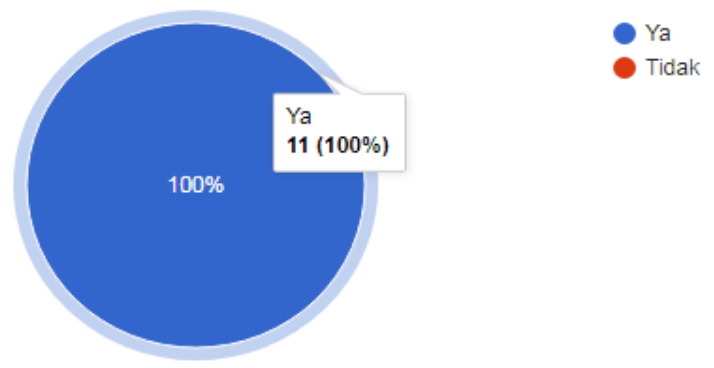

Berdasarkan hasil angket yang sudah diberikan kepada respndent menunjukkan hasil yang maksimal dimana $100 \%$ para responden setuju bahwa smart phone memberikan kesempatan kepada mahasiswa untuk melakukan presentasi terhadap ide/gagasan mereka. Dengan aplikasi smart phone yang mengakses media sosial mengajak siapa saja yang tertarik untuk berpertisipasi dengan memberi kontribusi dan feedback secara terbuka, memberi komentar, serta membagi informasi dalam waktu yang cepat dan tak terbatas. Menurut Ally (2009:143) penggunaan smartphone untuk pembelajaran berarti melakukan akses secara online dokumen, lingkungan belajar virtual, forum siswa dan situs web yang menunjang pembelajaran. Kegiatan pembelajaran termasuk penggunaan email, mengakses sumber belajar di 
web, mengunduh buku untuk dibaca, translate bahasa, dan kerja kelompok (berpartisipasi dalam kerja kelompok dari jarak jauh menggunakan handsfree).

Apakah smartphone memudahkan Anda untuk memberi informasi terkait mata kuliah yang diampu?

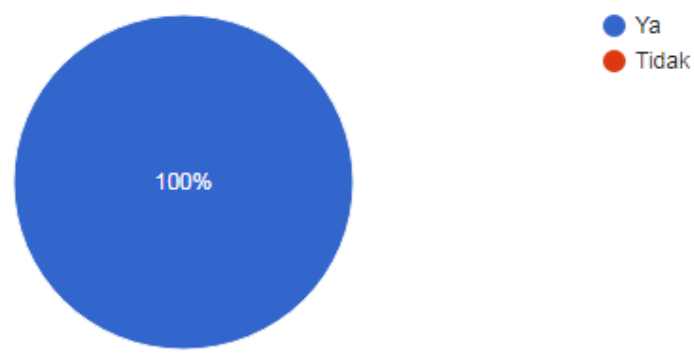

Merujuk pada hasil angket terhadap manfaat smartphone dalam memudahkan responden untuk memberikan informasi terkait mata kuliah yang diampu dan $100 \%$ respondents setuju dan tetunya hal ini memudahkan respondents dalam menyampaikan materi pembelajaran, Memudahkan mahasiswa untuk mengupload dan mengakses video presentasi, Mempermudah dalam penyampaian mata pelajaran walaupun terbatas dengan waktu serta sarana yang memadai, Mempermudah prosea belajar mengajar dan membuat Lebih praktis dan efisien untuk sharing informasi yang pada akhirnya menjadikan mahasiswa sebagai center pembelajaran. Woodil (2010:31) berpendapat bahwa Mobile Learning adalah pembelajaran personal yang menyatukan konsep pembelajaran dengan Cloud Computing menggunakan perangkat Mobile sehingga pembelajaran lebik efektif dan efesien.

2) Smartphone Sebagai Komunukasi Bagi Siswa

Apakah Anda menggunakan smartphone untuk seluruh kegiatan belajar-mengajar?

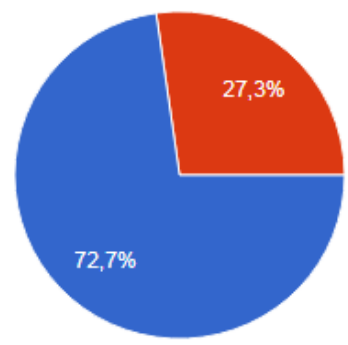

Dalam hal penggunaan smartphone untuk seluruh kegiatan belajar-mengajar respondent yang setuju sebnyak $72.7 \%$ memanfaatkan smartphone beserta aplikasinya untuk kegiatan belajar mengajar. Namun ada $27.3 \%$ responden tidak menggunakan smartphone untuk seluruh kegiatan belajar mengajar. Ada sebagian responden menggunakan smartphone untuk membagikan tugas atau mengumpulkan tugas untuk menunjang pembelajaran online dimasapandemi utamanya dngan sistem asynchronous. Asynchronous learning yaitu metode pembelajaran e-learning atau daring yang menggunakan perangkat learning management system (LSM) yang memungkinkan siswa mengakses bahan ajar/modul/konten secara mandiri tanpa harus bertatap muka/berkomunikasi langsung dengan pengajar. Asynchronous learning dapat berupa konten, forum diskusi, penugasan, kuis, dan sebagainya (Nasution, 2020: 31-32).
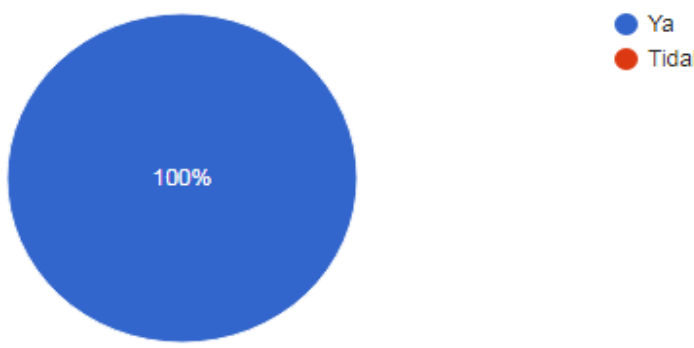

Tidak

Berkaitan dengan smartphone sebagai platform diskusi bagi mahasiswa, respondents setuju bahwa smartphone sebagai platform diskusi bagi mahasiswa. Menurut (Bahri et al., 2018). Model pembelajaran ini menggunakan teknologi yang mendukung bahan belajar tambaha dimanapun. Sementara waktu belajar di kelas digunakan oleh siswa untuk berdiskusi dengan teman sekelasnya, saling berbagi pendapat tentang kemampuan siswa. Hal ini dikarenakan smartphone membuat inreraksi dan Komunikasi dengan mahasiswa lebih mudah, Memudahkan untuk mahasiswa bediskusi satu sama lain bahkan diluar jam pengajaran, smart phone juga memudahkan pembelajaran jarak jauh yang membuat mahasiswa lebih kreatif dan percaya diri ketika diminta untuk membuat video presentasi, serta memperlancar komunikasi karena unlimited ruang dan waktu membuat smartphone menunjang komunikasi dan 
pembelajaran sehingga Praktis dan efisien.

3) Smartphone sebagai media Konstruksi Apakah anda menggunakan smartphone dalam memberikan umpan balik dan kesempatan kepada mahasiswa untuk secara mandiri membangun pengetahuan terhadap matakuliah Anda kepada mahasiswa?

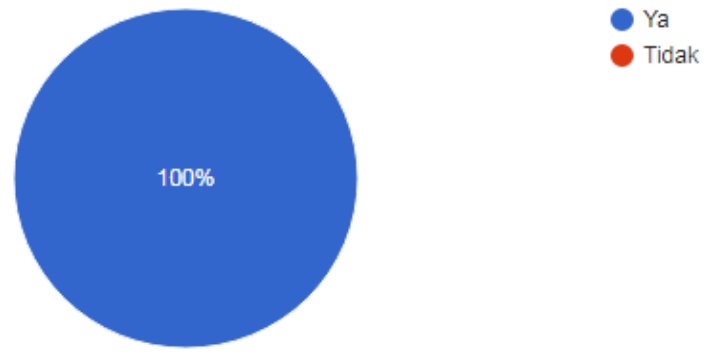

Berdasarkan pie chart yang disajikan diatas, $100 \%$ responden setuju bahwa smartphone dalam memberikan umpan balik dan kesempatan kepada mahasiswa untuk secara mandiri membangun pengetahuan terhadap mata kuliah. Menurut Gonzalez (2015:32) smartphone dapat memberikan kontribusi yang positif kepada pesertadidik untuk mengakses bahan belajar ataupun sebagai media pembelajaran. Selain itu, Laurillard (2007) berpendapat bahwa dengan menggunakan smartphone dalam pendidikan, membuat teknologi ini memiliki peran yang sentral untuk dapat digunakan sebagai sarana penyampai informasi kepada siswa melalui teknologi perangkat mobile. Karena dengan perangkat yang ada dalam smartphone memudahkan dosen dalam memberkan umpa balik, pengayaan dan memfasilitasi mahasiswa untuk membangun pengetahuannya secara mandiri.

Apakah pengajaran melalui aplikasi smartphone dapat meningkatkan keterampilan berpikir kritis bagi mahasiswa Anda?
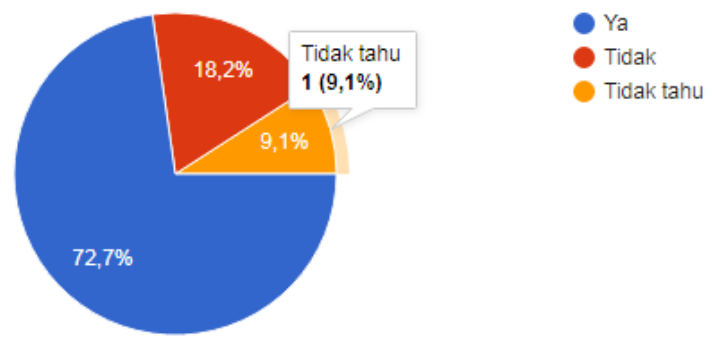

Dalam hal manfaat smartphone menunjang mahasiswa berfikir kritis, ada $72.7 \%$ responden setuju ada $18.2 \%$ tidak setuju dan 9.1\% mengungkapkan tidak tahu. Walaupun dalam hal tertentu memang terkadang prangkat di smartphone membuat mahasiswa malas berfikir kritiss, disisi lain smartphone memberikan dampak positif. Rogozin (2012:913) yang menyatakan bahwa dengan menggunakan smartphone sebagai media pembelajaran memberikan kesempatan belajar yang lebih mendalam bagi siswa karena dengan menggunakan smartphone siswa dapat mengembangkan pembelajaran melalui penelusuran informasi dari internet, serta melatih keterampilan mereka dalam melaksanakan praktikum karena prinsip mobilitas yang dimiliki oleh smartphone. Lebih lanjut dikatakan bahwa dengan menggunakan smartphone siswa mampu membangun kompetensi mereka dengan cara yang dinamis.

Apakah manfaat yang Anda rasakan dari penggunaan Smartphone sebagai media komunikasi dalam proses pengajaran dan apakah aplikasi smartphone yang sering Anda gunakan memberikan, merencanakan, memantau, dan mengevaluasi ketercapaian tujuan pembelajaran?
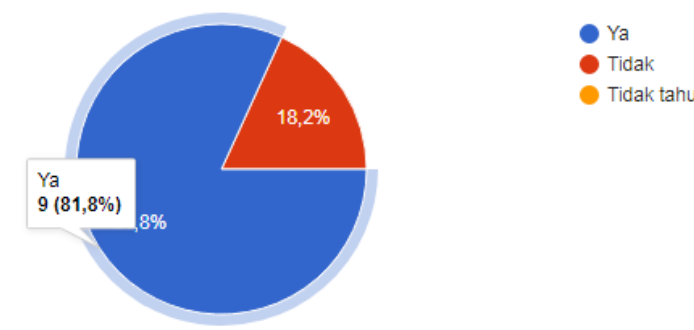

Terdapat $81.8 \%$ responden setuju bahwa aplikasi smartphone yang sering Anda gunakan memberikan, merencanakan, memantau, dan mengevaluasi ketercapaian tujuan pembelajaran. Seiring perkembangannya banyak sekali manfaat smartphone dalam pembelajaran. Menurut Woodil (2010:36) menjelaskan smartphone berkembang saat telepon selular semakin kecil dan mempunyai lebih banyak fitur dan kegunaan.utamanya dalam pembelajaran dikelas. Adapun manfaat dari penggunaan Smartphone sebagai media komunikasi dalam proses pengajaran adalah: Pembelajaran bisa dilaksanakan dimana saja, Materi pembelajaran mudah disampikan, Media construction contohnya memudahkan 
dalam memberikan feedback, Komunikasi bisa lebih mudah dan cepat, Mempermudah dalam pembelajaran walaupun terbatas dengan sarana jaringan internet, Prosea pengajaran lebih Praktis, efektive dan efisien. Dan terakhir Memberi kesempatan pada mahasiswa untuk berkomunikasi, Memudahkan mahasiswa mencari sumber belajar dengan cepat dan uptodate information.

4) Smartphone sebagai media Ekspresi Apakah Anda memberikan kesempatan kepada mahasiswa untuk bebas berdiskusi diluar jam mata kuliah melalui aplikasi smartphone dan Apakah Anda memberikan kesempatan kepada mahasiswa untuk mengungkapkan saran tentang jalannya perkuliahan?

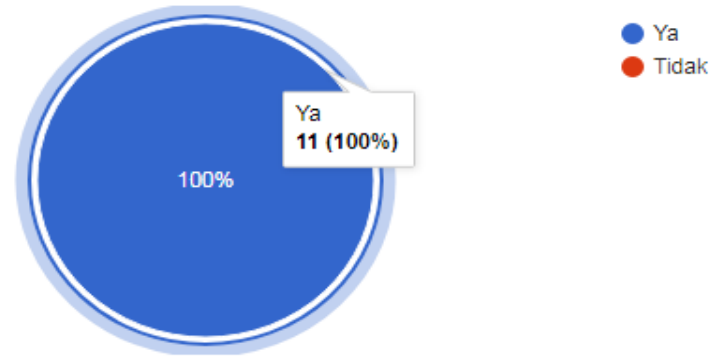

Semua responden setuju 100\% bahwa smartphone memberikan kesempatan kepada mahasiswa untuk bebas berdiskusi diluar jam mata kuliah dan melalui aplikasi smartphone ada banyak manfaat dari penggunaan Smartphone sebagai media ekspresi dalam proses pengajaran. Diantaranya mahasiswa dapat lebih mudah dalam mengungkapkan gagasan mereka dalam diskusi. Strategi pembelajaran bahasa telah banyak membuktikan bahwa setiap peserta didik memiliki gaya belajar yang berbeda-beda yang perlu diperhatikan oleh para guru (Rahayu:2019). Dengan gaya belajar yang berbeda beda tersebut dapat difasilitasi oleh beberapa aplikasi yang tersedia di smartphone. Beberapa aplikasi di smarphone memudahkan siswa dan menghilangkan anxiety mereka terhadap pembelajaran bahasa inggris. Dosen juga Lebih mudah mengevaluasi semua yang sudah kita kerjakan, sehingga kedepannya dosen mengetahui strategi apa yang lebih tepat diberikan kepada mahasiswa saat menyampaikan materi secara daring. Selanjutnya mahasiswa juga lebih mudah dan bebas mengungkapkan dan berekspresi serta sangat membantu untuk melatih keteampilan mereka utama dalam speaking contohnya, ketika mereka diminta buat video mereka meresa lebih natuiral dan relax mengekpresikan kemampuannya.

C. Kesulitan yang dihadapi oleh dosen dalam pemanfaatan aplikasi smartphone

Dari analisis kesulitan yang dihadapi oleh dosen dalam pemanfaatan aplikasi smartphone, didapatkan hasil bahwa sebanyak 63\% dosen mengalami kesulitan pada jaringan internet dari mahasiswa. Hal ini dikarenakan mayoritas mahasiswa berasal dari daerah terpencil yang tidak mempunyai akses internet sama sekali sehingga menjadi salah satu masalah utama pada pembelajaran daring selama era pandemi. Hal ini sejalan dengan pendapat Wahyuningsih et al., 2021 yang menyatakan bahwa permasalahan yang dialami pendidik pada saat pembelajaran daring yaitu keterbatasan fasiilitas pendukung dan akses jaringan internet. Hal yang sama juga diungkapkan oleh Wati \& Nora (2020), bahwa kendala yang dihadapi selama proses pembelajaran daring adalah jaringan di daerah pedesaan, listrik yang tidak memadai dan pembelian paket data yang tergolong mahal. Kesulitan-kesulitan ini membuat interaksi antara dosen dan mahasiswa kurang berjalan lancar selama pembelajaran.

Selain itu, kesulitan yang dihadapi adalah permasalahan pada keaslian tugas yang dikumpulkan oleh mahasiswa. Karena mudahnya mahasiswa mencari materi di situs internet dengan menggunakan smartphone membuat mereka tidak kreatif dan cenderung menyalin secara langsung dari sumber internet. Hal ini didukung oleh Abad \& García (2018) yang mengemukakan bahswa isu plagiarisme di dunia akademik bukanlah hal yang baru, dan telah menjadi ancaman bagi integritas ilmu pengetahuan. Pada kenyataannya, tidak banyak mahasiswa yang memahami batasan-batasan plagiarisme. Ini artinya ada kemungkinan plagiarisme dapat disebabkan oleh ketidaktahuan atau tanpa disengaja (accidental/unintentional plagiarism) daripada yang disengaja (deliberate/ intentional plagiarism) (Marshall \& Rowland, 1998).

Dalam pengajaran Bahasa Inggris selama pandemi, terdapat kesulitan pada mata kuliah yang membutuhkan lebih banyak praktik, 
seperti mata kuliah Survival English, Speaking, dan English Debate. Dikarenakan jaringan mahasiswa yang kurang memadai, maka kebanyakan penampilan tidak bisa dilakukan secara synchronous. Penggunaan video offline dinilai kurang efektif untuk bisa menilai langsung penampilan mereka. Hal ini dikarenakan penampilan dalam bentuk video memberikan kesempatan lebih kepada mereka untuk mengulang kembali percakapan atau monolog sehingga sulit melihat performa asli mereka. Hal ini sejalan dengan pendapat dari Wiramarta, 2021, yang menyatakan bahwa tantangan yang dihadapi pendidik selama masa pembelajaran daring adalah ketidakefektifan penilaian dan lemahnya pengawasan selama mereka menjalani proses pengambilan video menjadi kelemahan yang tidak bisa dihindarkan.

\section{SIMPULAN DAN SARAN}

\section{A. Simpulan}

Ada beberapa aplikasi smartphone yang paling sering digunakan sebagai media pembelajaran bahasa inggris oleh dosen yaitu whatsapp, google classroom, google meet dan facebook. Dari beberapa aplikasi di smartphone tersebut dapat disimpulkan bahwa aplikasi yang paling sering digunakan oleh dosen selama pembelajaran daring adalah whatsapp terlihat bahwa whatsapp yang paling banyak dipilih sebagai media pembelajaran. Hal ini dikarenakan whatsapp lebih praktis untuk digunakan sehari-hari, dan sarana komunikasi yang efektif bagi mahasiswa maupun dosen. Selain itu, bisa mengantarkan pesan, gambar, video, audio dan pesan suara dengan mudah, sehingga bisa mempermudah kegiatan belajar mengajar, terutama Bahasa Inggris. Ada beberapa manfaat smartphone dalam pembelajaran bahasa inggris yaitu: Smartphone Sebagai Media Inkuiri, Smartphone Sebagai Komunikasi Bagi Siswa, Smartphone, Sebagai Pusat Informasi Bagi Siswa, Smartphone Sebagai Media Konstruksi. Ada juga Kesulitan yang dihadapi oleh dosen dalam pemanfaatan aplikasi smartphone. Dosen mengalami kesulitan pada jaringan internet dari mahasiswa. Hal ini dikarenakan mayoritas mahasiswa berasal dari daerah terpencil yang tidak mempunyai akses internet sama sekali sehingga menjadi salah satu masalah utama pada pembelajaran daring selama era pandemi. Selain itu, kesulitan yang dihadapi adalah permasalahan pada keaslian tugas yang dikumpulkan oleh mahasiswa. Karena mudahnya mahasiswa mencari materi di situs internet dengan menggunakan smartphone membuat mereka tidak kreatif dan cenderung menyalin secara langsung dari sumber internet.

\section{B. Saran}

Saran yang dapat disampaikan oleh peneliti kepada peneliti berikutnya agar dapat menyampaikan terkait dengan manfaat dan efektivitas dari masing-masing platform digital yang digunakan dalam proses pembelajaran secara daring.

\section{DAFTAR RUJUKAN}

Abad-García, M. F. (2018). Plagiarism and predatory journals: A threat to scientific integrity. Anales de Pediatría (English Edition), 90(1), 57.e1-57.e8. doi: 10.1016/j.anpede.2018.11.006

Ally, Muhamed. (2009). Mobile learning: transforming the delivery of education and training. Québec: AU Press

Aunurrahman, Rahman Mifta, Purwaningsih Ismu.(2021). Analisis Penggunaan Google Classroom sebagai Media Pembelajaran. Jurnal Ilmiah Ilmu Pendidikan. Volume 4, Nomor 6, Oktober 2021 (445-449)

Barnett, J. E., \& Campbell, L. F. (2012). Ethics issues in scholarship. In S. J. Knapp (Ed.), PA handbook of ethics in psychology: Vol. 2. Practice, teaching, and research (pp. 309-333). Washington, DC: American Psychological Association.

Bua'a Olivia Ellasari, Irwan Dedy, Hafis Maliqul.(2021). Compulsory English Online Learning Practices In Kapuas Hulu Regency.Journal of English Language Teaching and Education. Vol. 2, No. 2, September 2021 (20-30)

Bahri, P. S., Zanuri \& Sukestiyarno. (2018). Problem Solving Ability on Independent Learning and

Goldfarb, A, N. Pregibon J. Shrem and E. Zyko (2011), "Informational Brief on Social Networking in Education," New York Comprehensive Center. 
Gonzalez, M.A., Martin, M.E., Liamas, C., et al. (2015). Teaching and learning physics with smartphones. Journal of Cases on Information Technology, 17, 31-50.

Hartatik, Sri Fatmaning \& Lestari, Hernina Dewi. (2021). Penggunaan Whatsapp Sebagai Media Komunikasi Pembelajaran Bahasa Inggris. Jurnal Nomosleca, 7(1), 45-56. https://doi.org/10.26905/nomosleca

Juniartini, N. M. E., \& Rasna, I. W. (2020). Pemanfaatan Aplikasi Google Meet Dalam Keterampilan Menyimak Dan Berbicara Untuk Pembelajaran Bahasa Pada Masa Pandemi Covid-19. Jurnal Pendidikan dan Pembelajaran Bahasa Indonesia, 9(2), 133141.

Latif, S. (2016). Learning Engagement in Virtual Environment. International Journal of Computer Application, 148(11), 7-13. Retrieved from https://www.ijcaonline.org/archives/volu me148/number11/25799-2016911289

Laurillard, D. (2007). edagogical forms for mobile learning in: Pachler, N. (ed) (2007) Mobile learning: towards a research agenda. London: WLE Centre, IoE.

Meliasari Rahayu.(2019. Exploring English Language Students' Learning Strategies in Reading ELT Materials. Journal of Applied Linguistics .Vol 1, No 1 (2019), pp.76-85

Nasution, Lafina Enthy. 2020. Uraian Singkat Tentang E-Learning. Yogyakarta: Deepublish.

Rahmawati, B., Utami, BH., Sudiyana, B., Rohadi, A. (2021). Penggunaan Google Classroom Dalam Pembelajaran Bahasa Indonesia Pada Masa Pandemi. Basastra: Jurnal Bahasa, Sastra, dan Pengajarannya, 9(1), 105-115.
Rogozin. (2012). Physics Learning Instruments of XXI Century. Proceedings of The World Conference on Physics Education 2012.

Setiyaningsih, L. A., \& Jatmikowati, S. H. (2019). Media Baru Dalam Komodifikasi Waktu Luang Ibu Rumah Tangga. ETTISAL: Journal of Communication, 4(1), 23-32.

Setiyaningsih, L. A. (2020). Media Panics Ibu Rumah Tangga Setelah Mengakses Berita Covid-19 (2020). Jurnal Nomosleca, 6(2), 101-110.

http://jurnal.unmer.ac.id/index.php/n/art icle/view/4721/2594

Wahyuningsih, K. S., Hindu, U., Gusti, N. I., \& Sugriwa, B. (2021). Problematika Pembelajaran Daring di Masa Pandemi Covid-19 di SMA Dharma Praja Denpasar, 24(1), 107-118. https://ejournal.ihdn.ac.id/index.php/PJA H/article/view/2185

Wati, Melda Novi \& AN Nora, Desri. (2020). Penggunaan Smartphone Sebagai Sumber Belajar Siswa Kelas XII IPS SMA Negeri 2 Lubuk Basung di Era Pandemi Pada Mata Pelajaran Sosiologi. Jurnal Sikola: Jurnal Kajian Pendidikan dan Pembelajaran, 2(1), 85-92.

Wiramarta, Kadek. (2021). Tantangan pembelajaran Bahasa Inggris pada Aspek Berbicara Pada Sekolah Pariwisata Dalam Masa Pandemi. Culture: Jurnal Ilmiah Pariwisata Nudaya Hindu, 2(1), 1-11.

Woodill, G. (2010). The mobile learning edge: Tools and technologies for developing your teams. McGraw Hill Professional. 